\title{
Comparison between the availability of iron in the presence of vitamin a and $\beta$-carotene in foods and medications
}

\author{
Comparação da disponibilidade de ferro na presença de vitamina a e \\ $\beta$-caroteno em alimentos e medicamentos
}

\author{
Fabiana Cristina Camargo MARTINI ${ }^{1}$, Solange Guidolin CANNIATTI-BRAZACA ${ }^{1 \star}$
}

\begin{abstract}
The objective of this work was to verify the availability of iron in the presence of vitamin A as components of foods and in combinations with medicines. The iron available was measured in the presence of vitamin A in foods - common bean (B), beef liver (Li) and carrot (C) - and medicines - Fer-In-Sol ${ }^{\oplus}$ (Fer) (Mead Johnson), Arovit $^{\circledR}$ (A) (Roche) and Neutrofer ${ }^{\oplus}$ (N) (Sigma Pharma) - as well as in combinations of both. $\beta$-carotene, vitamin $A$, total iron, heme and non heme iron, percentage of dialyzable iron and amount of dialyzable iron was determined. Vitamin A and $\beta$-carotene had a positive effect on the percentage of iron dialysis. Carrot and liver had a better percentage of dialyzable iron than their respective medicine at similar concentrations. Therefore, we can conclude that there has been an influence of vitamin A over the dialysis of iron, being the mixtures containing liver the ones which achieved the highest concentrations of dialyzable iron, and also that, according to the amounts needed to obtain the daily recommended intake of iron, they are good for consumption.
\end{abstract}

Keywords: iron; vitamin A; interaction; foods; medicine.

\section{Resumo}

O objetivo da pesquisa foi determinar a disponibilidade de ferro proveniente de alimentos e de medicamentos e sua combinação. Foi determinada a disponibilidade de ferro na presença de vitamina A em alimentos - feijão comum (B), fígado bovino (Li) e cenoura (C) - e em medicamentos - Fer-In-Sol ${ }^{\circledR}$ (Fer) (Mead Johnson), Arovit $^{\circledR}$ (A) (Roche) e Neutrofer ${ }^{\circledast}$ (N) (Sigma Pharma) - bem como na combinação de ambos. $\beta$-caroteno, vitamina $\mathrm{A}$, ferro total, ferro heme e não heme, porcentagem teor e diálise de ferro foram determinados. A vitamina A e $\beta$-caroteno têm efeito positivo na porcentagem de diálise de ferro. A cenoura e o fígado têm melhor disponibilidade de ferro que os medicamentos em concentrações similares. Portanto, conclui-se que existe a influência de vitamina A sobre a diálise de ferro, sendo as misturas que contêm fígado as que apresentaram as maiores concentrações de diálise de ferro, e que, de acordo com as quantidades de ferro necessárias diariamente recomendadas para consumo, elas são recomendadas.

Palavras-chave: ferro; vitamina A; interação; alimentos; medicamento.

\section{Introduction}

Iron deficiency and iron deficiency anemia are still a great problem for the Brazilian population. According to the World Health Organization (2002), about 66 to $80 \%$ of the world population is iron deficient and $54,9 \%$ of preschool-age children, $29,1 \%$ of pregnant women and $23,1 \%$ of non-pregnant women in reproductive age have anemia (WORLD HEALTH ORGANIZATION, 2008), which is caused especially by iron deficiency. Among the causes of iron-deficiency anemia, the inadequate or insufficient intake of iron sources can be observed.

Vitamin A is very important for the hematological conditions of iron in humans. The deficiency in this vitamin affects the transportation of iron, causing a low dosage of iron in the blood and a high concentration in the storage deposits, especially in the liver. This condition results in an irondeficiency like anemia, that will only respond to iron-based medication if a vitamin supplementation is previously given (WORLD HEALTH ORGANIZATION, 2007; HUNT, 2005).

Due to the harmful effects that iron deficiency has most specially on the health and the intellectual development of children, as well as to the importance of vitamin $\mathrm{A}$ in the recovery of this clinical condition, it is necessary and profitable to verify, among these foods and medicaments, which is the most efficient way to prevent these deficiencies.

The objectives of this work were to verify the availability of iron in the presence of vitamin A as components of foods common bean (B), beef liver ( $\mathrm{Li}$ ) and carrot $(\mathrm{C})$ - and in combinations with medicines - Fer-In-Sol ${ }^{\circ}$ (Fer) (Mead Johnson), Arovit ${ }^{\bullet}$ (A) (Roche) and Neutrofer ${ }^{\bullet}$ (N) (Sigma Pharma) - as well as to quantify the amount of heme iron, non-heme iron, retinol and $\beta$-carotene of the foods and their combinations with medicines. 


\section{Materials and methods}

The raw materials used were common beans (Phaseolus vulgaris L.), beef liver and carrot (Daucus carota L.). The medicines used were: ferrous sulfate solution (Fer-In-Sol ${ }^{\oplus}$, Mead Johnson); retinol acetate dragee (Arovit ${ }^{\oplus}$, Roche) and iron glycinate chelate tablets (Neutrofer ${ }^{\circledast}$, Sigma Pharma).

\subsection{Preparation of the samples}

The common beans sample was washed and left under deionized water maceration at room temperature for 16 hours at the proportion of 1:3 (bean: water). After this period, the water was drained and the sample was placed under maceration once again at the proportion of 1:2, and then, autoclaved at the temperature of $121{ }^{\circ} \mathrm{C}$ for 10 minutes (MOLINA; DE LA FUENTE; BRESSANI, 1975). After autoclaving, the grains, as well as the water added, were placed in a grinder and ground. The beef liver was cooked in an open stainless steel pan on medium temperature for about 15 minutes and no other ingredient was added. The carrots were washed, peeled and triturated in a home food processor (model MegaMaster Super by Walita). Preparation methods were based in habits, since humans usually eat raw carrots and cooked beans and liver.

\section{Elaboration of experimental combinations}

The analyses of iron dialysis, vitamin A and beta carotene were carried out before the samples were dried. For the other analyses, the samples were placed in an oven at $55-60{ }^{\circ} \mathrm{C}$ and then, grinded in a home food processor and put in closed plastic bags, which were stored in a refrigerator. All analyses were done in triplicate.

After the individual preparation, food samples were mixed, including the medicines when necessary. The amount of medicine added to the food was calculated after a previous analysis of the minerals and $\beta$-carotene compositions of the previously dried foods.
The amount of medicines added was similar to the amount found in the analysis of the correspondent foods. Hence, the amount of ferrous sulfate (Fer1) and iron aminochelate (N1) correspond to the amount of iron found in the bean sample (78.67 mg. $\mathrm{kg}^{-1}$ ); the amount of ferrous sulfate (Fer2) and iron aminochelate (N2) correspond to the iron concentration found in the liver sample (211.17 mg. $\left.\mathrm{kg}^{-1}\right)$; and the amount of vitamin A (A1) was calculated by converting the $\beta$-carotene amount found in the carrots (15 mg.100 $\mathrm{g}^{-1}$ fresh product). Liver has high amounts of iron and vitamin $\mathrm{A}$, therefore, it was necessary to subtract part of the iron and vitamin A that was added as medicines in the mix. The amount added for the liver mix for vitamin A was $8.25 \mathrm{mg} .100 \mathrm{~g}^{-1}$ and for iron $4.25 \mathrm{mg} .100 \mathrm{~g}^{-1}$.

Each Arovit ${ }^{\oplus}$ (Roche) dragee contains 50.000 IU, corresponding to about $17 \mathrm{mg}$ of retinol acetate. Each $\mathrm{mL}$ of the Fer-in-Sol ${ }^{\oplus}$ (Mead Johnson) solution contains $25 \mathrm{mg}$ of iron. Each Neutrofer ${ }^{\circledast}$ (Sigma Pharma) tablet $(300 \mathrm{mg}$ ) equals to $60 \mathrm{mg}$ of elementary iron. These medicines were selected due to their price and for being of common use.

The blends of foods and medicines that originated the combinations are presented in Table 1.

\subsection{Methods}

The analyses of retinol and $\beta$-carotene were carried out at 'Instituto de Tecnologia de Alimentos' (ITAL - Campinas, Brazil), through High Performance Liquid Chromatography (HPLC) (MANZ; PHILIPP, 1988; CARVALHO; COLLINS; RODRIGUES-AMAYA, 1992) and the results were converted into International Units of vitamin A (IU), using the following conversion factor: 1.8 for $\beta$-carotene and $0.3 \mathrm{mcg}$ of retinol for 1 IU (NATIONAL RESEARCH COUNCIL, 1989).

\section{Determination of non-heme iron}

The samples containing liver and its blends were weighed and added to $15 \mathrm{~mL}$ of extracting solution composed by the

Table 1. The blends of foods and medicines originated the combinations.

\begin{tabular}{|c|c|c|c|c|c|c|}
\hline Blends & Carrot & Bean & Liver & Arovit $^{\circledR}$ & Neutrofer $^{\circledR}$ & Fer-in-Sol $^{\circledR}$ \\
\hline $\mathrm{C}$ & $100 \mathrm{~g}$ & - & - & - & - & - \\
\hline $\mathrm{C}+\mathrm{N} 1$ & $100 \mathrm{~g}$ & - & - & - & $39,3 \mathrm{mg}$ & - \\
\hline $\mathrm{C}+\mathrm{N} 2$ & $100 \mathrm{~g}$ & - & - & - & $105,58 \mathrm{mg}$ & - \\
\hline $\mathrm{C}+\mathrm{Fer} 1$ & $100 \mathrm{~g}$ & - & - & - & - & $0,32 \mathrm{~mL}$ \\
\hline$C+$ Fer2 & $100 \mathrm{~g}$ & - & - & - & - & $0,84 \mathrm{~mL}$ \\
\hline$C+B$ & $100 \mathrm{~g}$ & $100 \mathrm{~g}$ & - & - & - & - \\
\hline B & - & $100 \mathrm{~g}$ & - & - & - & - \\
\hline $\mathrm{B}+\mathrm{A} 1$ & - & $100 \mathrm{~g}$ & - & $731 \mathrm{mg}$ & - & - \\
\hline $\mathrm{B}+$ Fer 2 & - & $100 \mathrm{~g}$ & - & - & - & $0,84 \mathrm{~mL}$ \\
\hline $\mathrm{B}+\mathrm{N} 2$ & - & $100 \mathrm{~g}$ & - & - & $105,58 \mathrm{mg}$ & - \\
\hline $\mathrm{B}+\mathrm{Li}$ & - & $100 \mathrm{~g}$ & $100 \mathrm{~g}$ & - & - & - \\
\hline $\mathrm{Li}$ & - & - & $100 \mathrm{~g}$ & - & - & - \\
\hline $\mathrm{Li}+\mathrm{A} 1$ & - & - & $100 \mathrm{~g}$ & $402,23 \mathrm{mg}$ & - & - \\
\hline $\mathrm{Li}+\mathrm{Fer} 1$ & - & - & $100 \mathrm{~g}$ & - & - & $0,17 \mathrm{~mL}$ \\
\hline $\mathrm{Li}+\mathrm{N} 1$ & - & - & $100 \mathrm{~g}$ & - & $21,63 \mathrm{mg}$ & - \\
\hline $\mathrm{Li}+\mathrm{C}$ & $100 \mathrm{~g}$ & - & $100 \mathrm{~g}$ & - & - & - \\
\hline
\end{tabular}

C = Carrot, B = Bean, Li = Liver, A1 = Arovit (15 mg), Fer1 = Fer-In-Sol (78.67 mg), Fer2 = Fer-In-Sol (211.17 mg), N1 = Neutrofer (78.67 mg), N2 = Neutrofer (211.17 mg). 
mixture $1: 1$ of $40 \%$ trichloroacetic acid and $\mathrm{HCl} 6$ mol. $\mathrm{L}^{-1}$ (SCHRICKER; MILLER; STOUFFER, 1982). Sodium nitrite (1\%) was added and then, samples were put in a hot water bath $\left(53{ }^{\circ} \mathrm{C}\right)$ for 18 hours, next, they were cooled and centrifuged for 10 minutes. The non-heme iron in supernatant sample was analyzed through Ferrozine's method, described by Carpenter and Clark (1995). In Ferrozine's method the samples received a reducing agent at $1 \%$ (ascorbic acid) and protein precipitant at $11.3 \%$ (tricloroacetic acid) and were centrifuged. Ammonium acetate (20\%) was added to the supernatant, and then Ferrozine's reagent $1 \mathrm{mmol} . \mathrm{L}^{-1}$ was added. This mixture resulted in the development of a magenta complex which was determined by absorbance at $562 \mathrm{~nm}$.

\section{Determination of heme iron}

The determination of heme iron was made according to the methodology described by Hornsey (1956), with some adaptations, which are based on acidified acetone extraction. The liver samples and their blends were placed in centrifuge tubes and $20 \mathrm{~mL}$ of acetone and $0.5 \mathrm{~mL}$ of $\mathrm{HCl}$ were added. Then, water was added up until the total volume of water and meat was equal to $4.5 \mathrm{~g}$. The samples were then mixed for 15 seconds and filtered. The absorbance of the filtered matter was measured at $640 \mathrm{~nm}$ and the content of heme iron was calculated. The content of water in the meat samples was determined by drying them at $105^{\circ} \mathrm{C}$ for 16 hours (ASSOCIATION..., 1995).

\section{In vitro iron dialysis}

The iron dialysis was carried out according to the method proposed by Whittaker, Fox and Forbes (1989). The samples were homogenized in deionized water and $\mathrm{HCl} 6$ mol.L $\mathrm{L}^{-1}$ was added until $\mathrm{pH}$ reached 2 . Next, $\mathrm{HCl} 0.01$ mol.L $\mathrm{L}^{-1}$ was added until the volume of $100 \mathrm{~mL}$ was reached. The digestion was done by adding $\mathrm{HCl}$-pepsin with incubation at $37^{\circ} \mathrm{C}$ and agitation at $200 \mathrm{rpm}$ for 2 hours. The titratable acidity was carried out by adding pancreatine-bile solution followed by titration with $\mathrm{KOH} 0.5$ mol. $\mathrm{L}^{-1}$ until $\mathrm{pH}$ reached 7.5 from the titratable $\mathrm{KOH}$ volume, a dilution of the same volume of $\mathrm{NaHCO} 30.5$ mol.L $\mathrm{L}^{-1}$ was prepared.

The dialysis was carried out by placing the digested matter in dialysis membranes, in forms of bags, and adding the threefold volume of $\mathrm{NaHCO} 30.5 \mathrm{~mol} . \mathrm{L}^{-1}$ so that the digested matter became submersed. The containers were covered and agitated for 30 minutes at $37{ }^{\circ} \mathrm{C}$. A bile/pancreatine suspension was added, with two-hour incubation. The dialyzable was diluted to final volume of $25 \mathrm{~mL}$ with deionized water. After that, $5 \mathrm{~mL}$ of the dialyzed matter was pipetted into the centrifuge tube and some protein precipitant solution was added. Chromogenic solution was added to the supernatant. Ten minutes later, a reading was done at $533 \mathrm{~nm}$ in a Beckman DU 640 model spectrophotometer. The amount of dialyzed iron was achieved through a standard curve previously prepared. The results were expressed in percentage.

\section{Amount of iron available}

The amount of iron available was calculated from a percentage of the dialyzable iron in order to make the comparison of the samples.

For the liver samples, which have heme and non-heme iron, the amount of heme and non-heme iron was necessary, considering only $25 \%$ of the heme iron amount, as suggested by the literature (COTRAN; KUMAR; ROBBINS, 1996) as being the real absorbed amount.

\subsection{Statistical analysis}

The experimental outline was randomly employed, with three repetitions per treatment (sample). The results were submitted to variance analysis through the F test. Tukey's test was carried out for samples which obtained significance level of $5 \%$ in the $\mathrm{F}$ test. The analyses were done by the Statistical Analysis System (1996).

\section{Results and discussion}

Retinol (mg.100 g $\left.\mathrm{g}^{-1}\right), \beta$-carotene $\left(\mathrm{mg} .100 \mathrm{~g}^{-1}\right)$ and vitamin A (IU.100 $\mathrm{g}^{-1}$ ) concentrations are presented in Table 2 and the values are expressed on a wet matter basis. Table 3 shows the concentrations of heme and non-heme iron in $\mathrm{mcg}^{-1} \mathrm{~g}^{-1}$ on a wet basis. Table 4 shows the concentrations of iron $\left(\mathrm{mg} \cdot \mathrm{kg}^{-1}\right)$, dialyzable iron (\%) and the amount of iron available $\left(\mathrm{mg} \cdot \mathrm{kg}^{-1}\right)$.

The amount of vitamin A in food is usually expressed in IU. $100 \mathrm{~g}^{-1}$. For this reason, the values of retinol and $\beta$-carotene were converted into vitamin $\mathrm{A}$ and added when present in the same sample. For the carrot, the amount of vitamin A was lower than that described by Philippi (2001), which was 9,376.66 IU.100 $\mathrm{g}^{-1}$. For the liver, the vitamin A concentration was higher than 3439.59 IU.100 $\mathrm{g}^{-1}$ (PHILIPPI, 2001).

The $\beta$-carotene value (Table 2 ) is in accordance with other authors, such as Lee, Kim and Choe (2004) and Rajagopal et al. (2007), who obtained values from 4.6 to $10.3 \mathrm{mg} .100 \mathrm{~g}^{-1}$.

The amount of heme iron and non-heme iron was determined only in the samples containing liver (Table 3 ). The variation of heme iron showed similar values to Kongkachuichai; Napatthalung; Charoensiri (2002), who found $23 \mathrm{mcg} \cdot \mathrm{g}^{-1}$ of heme iron for fried liver, the total amount of iron in beef, and found, on average, $11 \mathrm{mcg}$. $\mathrm{g}^{-1}$ of heme iron. The concentration of non-heme iron for the liver was lower than that found by Kongkachuichai, Napatthalung and Charoensiri (2002), who found $103 \mathrm{mcg} . \mathrm{g}^{-1}$ for liver. Kongkachuichai, Napatthalung and Charoensiri (2002) found the average of $13 \mathrm{mcg} \cdot \mathrm{g}^{-1}$ for the meat samples. The difference was by different temperatures and types of process.

The percentage of dialyzable iron quantifies only a fraction of non-heme iron of a food (Table 4). As to the samples containing liver this percentage was low, because the liver is composited partly of heme iron and partly of non-heme iron. Heme iron is present in meat and other products (SOUZA; ARTHUR; CANNIATTI-BRAZACA, 2007; SOUZA, et al., 2008; 
Table 2. Concentration of vitamin A, retinol, and $\beta$-carotene, on a wet matter basis.

\begin{tabular}{|c|c|c|c|}
\hline Sample & Vitamin A (IU.100 g $\left.{ }^{-1}\right)$ & Retinol (mg.100 g $\left.\mathrm{g}^{-1}\right)$ & $\beta$-carotene $\left(\mathrm{mg} .100 \mathrm{~g}^{-1}\right)$ \\
\hline $\mathrm{C}$ & 3569 & nd & $6.42 \pm 0.07^{b}$ \\
\hline $\mathrm{C}+\mathrm{N} 1$ & 3024 & nd & $5.45 \pm 0.50^{\mathrm{bc}}$ \\
\hline $\mathrm{C}+\mathrm{N} 2$ & 2660 & nd & $4.79 \pm 0.0^{\mathrm{cd}}$ \\
\hline $\mathrm{C}+\mathrm{Fer} 1$ & 3131 & nd & $5.64 \pm 0.64^{\mathrm{bc}}$ \\
\hline$C+$ Fer2 & 3458 & nd & $6.23 \pm 0.33^{b}$ \\
\hline$C+B$ & 2247 & nd & $4.05 \pm 0.13^{\mathrm{de}}$ \\
\hline $\mathrm{B}+\mathrm{A} 1$ & 8607 & $2.58 \pm 0.10^{\mathrm{e}}$ & nd \\
\hline B + Fer2 & nd & nd & nd \\
\hline $\mathrm{B}+\mathrm{N} 2$ & nd & nd & nd \\
\hline $\mathrm{B}+\mathrm{Li}$ & 26543 & $7.96 \pm 0.45^{\mathrm{d}}$ & nd \\
\hline $\mathrm{Li}$ & 71285 & $21.39 \pm 0.88^{\mathrm{a}}$ & nd \\
\hline $\mathrm{Li}+\mathrm{A} 1$ & 63439 & $19.04 \pm 2.40^{\mathrm{ab}}$ & nd \\
\hline
\end{tabular}

${ }^{*}$ Average \pm standard deviation $(\mathrm{n}=3)$. Values in the same column, followed by different letters, show significant difference ( $\left.\mathrm{p} \leq 0.05\right)$; $\mathrm{nd}-\mathrm{value}$ not determined. $\mathrm{C}=\mathrm{Carrot}, \mathrm{B}=\mathrm{Bean}$, $\mathrm{Li}=$ Liver, A1 = Arovit (15 mg), Fer1 = Fer-In-Sol (78.67 mg), Fer2 = Fer-In-Sol (211.17 mg), N1 = Neutrofer (78.67 mg), N2= Neutrofer (211.17 mg).

Table 3. Concentration of heme and non-heme iron, on a wet matter basis.

\begin{tabular}{|c|c|c|}
\hline Sample & Heme iron $\left(\mathrm{mcg} \mathrm{g}^{-1}\right)$ & Non-heme iron $\left(\mathrm{mcg} \cdot \mathrm{g}^{-1}\right)$ \\
\hline $\mathrm{B}+\mathrm{Li}$ & $13.06 \pm 0.04^{* \mathrm{f}}$ & $7.11^{\mathrm{c}}$ \\
\hline $\mathrm{Li}$ & $31.85 \pm 0.41^{\mathrm{a}}$ & $7.42 \pm 0.01^{\mathrm{b}}$ \\
\hline $\mathrm{Li}+\mathrm{A} 1$ & $27.20 \pm 0.18^{\mathrm{d}}$ & $3.42 \pm 0.02^{\mathrm{e}}$ \\
\hline $\mathrm{Li}+\mathrm{Fer} 1$ & $29.00 \pm 0.06^{\mathrm{b}}$ & $9.48^{\mathrm{a}}$ \\
\hline $\mathrm{Li}+\mathrm{N} 1$ & $27.84 \pm 0.11^{\mathrm{c}}$ & $6.97 \pm 0.03^{\mathrm{d}}$ \\
\hline $\mathrm{Li}+\mathrm{C}$ & $17.21 \pm 0.21^{\mathrm{e}}$ & $2.54 \pm 0.01^{\mathrm{f}}$ \\
\hline
\end{tabular}

${ }^{\star}$ Average \pm standard deviation $(\mathrm{n}=3)$. Values in the same column, followed by different letters, show significant difference $(\mathrm{p} \leq 0.05) ; \mathrm{C}=\mathrm{Carrot}, \mathrm{B}=\mathrm{Bean}, \mathrm{Li}=\mathrm{Liver}, \mathrm{Al}=\mathrm{Arovit}$ $(15 \mathrm{mg})$, Fer1 = Fer-In-Sol (78.67 mg), Fer2 = Fer-In-Sol $(211.17 \mathrm{mg}), \mathrm{N} 1=$ Neutrofer $(78.67 \mathrm{mg})$, N2 = Neutrofer $(211.17 \mathrm{mg})$.

Table 4. Concentration of iron ( $\left.\mathrm{mg} \cdot \mathrm{kg}^{-1}\right)$, percentage of dialyzable iron and amount of iron available $\left(\mathrm{mg}^{\mathrm{kg}} \mathrm{kg}^{-1}\right)$, on a wet matter basis.

\begin{tabular}{|c|c|c|c|}
\hline Sample & Iron $\left(\mathrm{mg} \cdot \mathrm{kg}^{-1}\right)$ & Dialyzable iron (\%) & Amount of iron available $\left(\mathrm{mg} \cdot \mathrm{kg}^{-1}\right)$ \\
\hline $\mathrm{C}$ & $4.01 \pm 0.21^{* 1}$ & $8.71 \pm 0.01^{*} \mathrm{e}$ & 0.35 \\
\hline $\mathrm{C}+\mathrm{N} 1$ & $5.56 \pm 0.16^{\mathrm{kl}}$ & $13.59 \pm 0.91^{\mathrm{c}}$ & 0.76 \\
\hline $\mathrm{C}+\mathrm{N} 2$ & $9.19 \pm 0.16^{j}$ & $1.96 \pm 0.12^{\mathrm{h}}$ & 0.18 \\
\hline $\mathrm{C}+$ Fer 1 & $13.43 \pm 0.26^{\mathrm{i}}$ & $1.11 \pm 0.01^{\mathrm{ij}}$ & 0.15 \\
\hline $\mathrm{C}+\mathrm{Fer} 2$ & $27.97 \pm 0.30^{\mathrm{h}}$ & $1.06 \pm 0.01^{\mathrm{ij}}$ & 0.30 \\
\hline $\mathrm{C}+\mathrm{B}$ & $7.92 \pm 0.51^{\mathrm{jk}}$ & $3.50 \pm 0.00^{\mathrm{fg}}$ & 0.28 \\
\hline$B+$ Fer2 & $72.57 \pm 2.80^{\mathrm{e}}$ & $0.42 \pm 0.03^{j}$ & 0.30 \\
\hline $\mathrm{B}+\mathrm{N} 2$ & $34.91 \pm 0.47^{\mathrm{g}}$ & $1.81 \pm 0.00^{\mathrm{h}}$ & 0.63 \\
\hline $\mathrm{B}+\mathrm{Li}$ & $55.18 \pm 0.85^{\mathrm{f}}$ & $2.94 \pm 0.01^{\mathrm{g}}$ & 3.48 \\
\hline $\mathrm{Li}$ & $102.56 \pm 1.02^{\mathrm{c}}$ & $1.91 \pm 0.08^{\mathrm{h}}$ & 8.10 \\
\hline $\mathrm{Li}+\mathrm{A} 1$ & $98.47 \pm 1.84^{\mathrm{d}}$ & $14.69 \pm 0.03^{b}$ & 7.3 \\
\hline
\end{tabular}

${ }^{*}$ Average \pm standard deviation $(\mathrm{n}=3)$. Values in the same column, followed by different letters, show significant difference $(\mathrm{p} \leq 0.05) ; \mathrm{C}=\mathrm{Carrot}, \mathrm{B}=\mathrm{Beans}, \mathrm{Li}=\mathrm{Liver}, \mathrm{Al}=\mathrm{Arovit}$ $(15 \mathrm{mg})$, Fer1 = Fer-In-Sol $(78.67 \mathrm{mg})$, Fer2 = Fer-In-Sol $(211.17 \mathrm{mg}), \mathrm{N} 1$ = Neutrofer $(78.67 \mathrm{mg}), \mathrm{N} 2$ = Neutrofer $(211.17 \mathrm{mg})$. 
VALENZUELA et al., 2009). Therefore, in order to know the real concentration of iron in the liver samples, we must add the fraction of heme iron, which is the majority in this food, to the fraction of non-heme iron. Considering the foods individually, the carrot had the highest percentage of dialyzable iron, followed by liver and bean. When the medicines were added to the carrot samples, an increase in the percentage of dialyzable iron was observed with the addition of Neutrofer1. However, if the concentration of Neutrofer (N2) is increased, this percentage decreases considerably, because high iron amount decreases the dialysability of iron. The lower percentage of dialyzable iron in the carrot samples was observed for the samples of $\mathrm{C}+$ Fer 1 and $\mathrm{C}+$ Fer2, having no significant difference between the two concentrations of Fer-In-Sol (Fer1 and Fer2) studied. C + N2 presented higher percentage of dialyzable iron than $\mathrm{C}+\mathrm{Fer} 1$ and $\mathrm{C}+\mathrm{Fer}$, because the iron glycinate chelate is more available than ferrous sulfate.

For the bean samples, there was an increase in the percentage of dialyzable iron with the addition of Neutrofer and Arovit. As to Fer-In-Sol 2 this percentage was reduced in $50 \%$, because the iron form is different among Neutrofer and Fer-in-Sol. When iron is linked with aminoacids, the interaction with other substances does not occur (HURRELL et al., 2006; LAKSHMI; GUPTA; PRAKASH, 2006).

The addition of medicines to liver showed better results for all samples because of the presence of aminoacid contents in the liver, which increases the iron availability (HALLBERG; HULTHEN, 2002; SWAIN; TABATABAI; REDDY, 2002).

If we consider the food blends, the $\mathrm{Li}+\mathrm{C}$ blend showed a higher percentage of dialyzable iron than $\mathrm{C}+\mathrm{B}$ and $\mathrm{B}+\mathrm{Li}$. If we compare the performance of the medicines in the foods, the percentage of dialyzable iron showed a better result for the $\mathrm{C}+\mathrm{N} 1$ sample than for the $\mathrm{C}+\mathrm{B}$ sample. As to the $\mathrm{C}+\mathrm{Fer} 1$ blend, the $\mathrm{C}+\mathrm{B}$ sample presented better results. However, the liver-added carrot had a much better result than the respective concentrations of iron in medicines Fer-In-Sol 2 and Neutrofer2.

Similar to bean samples, the addition of carrots showed better results than the addition of Arovit. The addition of liver presented better results than the medicines $(\mathrm{C}+\mathrm{N} 2$ and $\mathrm{C}+$ Fer2). Thus, for the beans samples, the addition of carrot and liver were more efficient to increase the percentage of dialyzable iron than the use of the respective medicines.

In the comparison of the liver sample, the $\mathrm{Li}+\mathrm{C}$ blend was also more effective than the $\mathrm{Li}+\mathrm{A} 1$ sample. Notwithstanding, the $\mathrm{Li}+\mathrm{Fer} 1$ sample had better results than $\mathrm{Li}+\mathrm{B}$ and $\mathrm{Li}+\mathrm{N} 1$. Therefore, the addition of carrots to the beans and liver samples was more effective in the improvement of the percentage of dialyzable iron than its corresponding medicine (Arovit).

The total intake of iron in a food or diet does not correspond to the amount that will be bioavailable, because there are several factors which influence the absorption and use of this mineral (LYNCH; STOLTZFUS, 2003; STORCKSDIECK et al., 2008). Consequently, in order to ensure an adequate support of iron, it is necessary to distinguish the total iron amount from the bioavailable amount (CONWAY; POWELL; GEISSLER, 2007). The amount of bioavailable iron is related to the measurement of food iron fraction, which can be absorbed by the gastrointestinal tract and, later on, be stored and incorporated to heme iron (HOPPLER et al., 2008; ).

The amount of iron available in the carrot sample was $0.35 \mathrm{mg} \cdot \mathrm{kg}^{-1}$. The addition of iron medicines did not increase the concentration of available iron, except for sample $(\mathrm{C}+\mathrm{N} 1)$, whose available iron concentration doubled. Regarding the addition of foods, sample $(C+B)$ presented a lower concentration of available iron than sample $(\mathrm{Li}+\mathrm{C})$.

The beans sample presented a poor availability of iron compared to the others. This is partly due to the concentration of diet fiber and anti-nutritional compounds in beans, which interfere negatively to the availability of non-heme iron. The addition of vitamin $A(B+A 1)$ and $\beta$-carotene $(C+B)$ improved the amount of iron available in the beans samples. Carrot was more efficient than the respective concentration of medicine. The addition of iron as medicine also improved the availability of iron in beans. Sample B + Li $\left(3.48 \mathrm{mg} \cdot \mathrm{kg}^{-1}\right)$ presented the highest amount of available iron among the beans samples.

According to Garcia-Casal (2006) and Chiplonkar and Agte (2006), vitamin A and $\beta$-carotene have a promoting effect on the absorption of iron from cereals, especially those with inhibitors such as fitates. According to Gargari et al. (2006); Villalpando et al. (2006); Zimermann et al. (2006) and Gunnarisson, Thorsdottiri and Palsson (2007) the presence of vitamin A forms a complex with iron, making it soluble in the intestines and avoiding the inhibitory effect of fitates and polyphenols on non-heme iron absorption.

The highest amount of iron available was observed in the liver sample $\left(8.10 \mathrm{mg} \cdot \mathrm{kg}^{-1}\right)$ and its blends. This result was expected due to the characteristics of liver, such as the presence of heme iron and proteins. The liver sample also showed the highest concentrations of vitamin $\mathrm{A}$ and heme iron. The addition of the blends to the liver samples did not improve the amount of iron available, once heme iron is little influenced by the dietary components. However, if we compare the performance of the medicines to the foods, the medicines were more efficient than the latter.

Regarding the combination of foods, $\mathrm{Li}+\mathrm{C}$ blend offered the highest concentration of available iron $\left(4.80 \mathrm{mg} \cdot \mathrm{kg}^{-1}\right)$, followed by $\mathrm{Li}+\mathrm{B}\left(3.48 \mathrm{mg} \cdot \mathrm{kg}^{-1}\right)$ and C $+\mathrm{B}\left(0.28 \mathrm{mg} \cdot \mathrm{kg}^{-1}\right)$.

\section{Conclusions}

The concentrations of vitamin $A$ and $\beta$-carotene evaluated had a positive effect on the iron dialysis percentage.

The carrot and the liver showed better percentages of dialyzable iron than their respective medicines at similar concentrations, being, thus, more effective.

Therefore, we can conclude that there was an influence of vitamin A on the dialysis of iron and that liver blends were the ones with the best available iron concentrations in relation to the medicine. 


\section{Acknowledgements}

We would like to thank 'Escola Superior de Agricultura "Luiz de Queiroz"/University of São Paulo (ESALQ/USP), 'Coordenadoria de Aperfeiçoamento de Pessoal' (CAPES) and 'Fundação de Amparo a Pesquisa do Estado de São Paulo' (FAPESP) for the financial support to this research.

\section{References}

ASSOCIATION OF OFFICIAL ANALYTICAL CHEMISTS - AOAC. Official Methods of Analysis of the Association of Official Analytical Chemists. 16th ed. Washington: AOAC. 1995. v. 2.

BENOIST, B. et al. Worldwide prevalence of anaemia 1993-2005. WHO Global database on anaemia. Geneva: WHO, 2008. 40 p.

CARPENTER, C. E.; CLARK, E. Evaluation of methods used in meat iron analysis and iron content of raw and cooked meats. Journal of Agricultural and Food Chemistry, v. 43, n. 7, p. 1824-1827, 1995. http://dx.doi.org/10.1021/jf00055a014

CARVALHO, P. R. N.; COLLINS, C. A.; RODRIGUEZ-AMAYA, D. B. Comparison of determination by normal-phase gravity-fow column chromatography and reversed phase high performance liquid chromatography. Chromatography, v. 33, n. 3-4, p. 133-137, 1992. http://dx.doi.org/10.1007/BF02275893

CHIPLONKAR, S. A.; AGTE, V. V. Statistical model for predicting non-heme iron bioavailability from vegetarian meals. International Journal of Food Science and Nutrition, v. 57, n. 7, p. 434-450, 2006. PMid:17162323. http://dx.doi.org/10.1080/09637480600836833

CONWAY, R. A.; POWELL, J. J.; GEISSLER, C. A. A food-group based algorithm to predict non-heme iron absorption. International Journal of Food Sciences and Nutrition, v. 58, n. 3, p. 29-41, 2007. PMid:17415954. http://dx.doi.org/10.1080/09637480601121250

COTRAN, R. S.; KUMAR, V.; ROBBINS, S. L. Patologia estrutural e funcional. Rio de Janeiro: Guanabara, 1996. 1277 p.

GARCÍA-CASAL, M. N. Carotenoids increase iron absorption from cereal-based food in the human. Nutrition Research, v. 26, n. 7, p. 340-344, 2006.

GARGARI, B. P. et al. Effect of retinol on iron bioavailability from Iranian bread in a Caco-2 cell culture model. Nutrition, v. 22, n. 6, p. 638-644, 2006. PMid:16635564. http://dx.doi.org/10.1016/j. nut.2006.02.005

GUNNARISSON, B. S.; THORSDOTTIR, I.; PALSSON, G. Associations of iron status with dietary and other factors in 6-yearold children. European Journal of Clinical Nutrition, v. 61, n. 3, p. 398-403, 2007. PMid:16988649. http://dx.doi.org/10.1038/ sj.ejcn. 1602529

HALLBERG, L.; HULTHEN, L. Perspectives on iron absorption. Blood Cells Molecules and Diseases, v. 29, n. 3, p. 562-573, 2002. http:// dx.doi.org/10.1006/bcmd.2002.0603

HOPPLER, M. et al. Ferritin-iron is released during boiling and in vitro gastric digestion. Journal of Nutrition, v. 138, n. 5, p. 878-884, 2008.

HORNSEY, H. C. The color of cooked cured pork. Journal of Science and Food Agriculture, v. 7, n. 8, p. 534-540, 1956. http://dx.doi. org/10.1002/jsfa.2740070804

HUNT, J. R. Dietary and physiological factors that effect the absorption and bioavailability of iron. International Journal for vitamin and Nutrition Research, v. 75, n. 6, p. 375-384, 2005. http://dx.doi. org/10.1024/0300-9831.75.6.375
HURRELL, R. L. et al. Meat protein fractions enhance nonheme iron absorption in humans. Journal of Nutrition, v. 136, n. 11, p. 2808-2812, 2006.

KONGKACHUICHAI, R.; NAPATTHALUNG, P.; CHAROENSIRI, R. Heme and nonheme iron content of animal products commonly consumed in Thailand. Journal of Food Composition and Analysis, v. 15, n. 4, p. 389-398, 2002. http://dx.doi.org/10.1006/ jfca.2002.1080

KRAEMER, K.; ZIMMERMANN, M. B.( Ed.). Nutritional Anemia. Basel: Sight and Live Press, 2007. 400 p.

LAKSHMI, A. J.; GUPTA, S.; PRAKASH, J. Comparative analysis of influence of promoters and inhibitors on in vitro available iron using two methods. International Journal of Food Sciences and Nutrition, v. 57, n. 7, p. 559-569, 2006. PMid:17162335. http:// dx.doi.org/10.1080/09515070601043328

LEE, J.; KIM, M.; CHOE, E. Effects of carrot powder in dough on the lipid oxidation and carotene content of fried dough during storage in the dark. Journal of Food Science, v. 69, n. 5, p. C411-C414, 2004.

LYNCH, S. R.; STOLTZFUS, R. J. Iron and ascorbic acid: Proposed fortification levels and recommended iron compounds. Journal of Nutrition, v. 133, n. 9, p. 2978S-2984S, 2003.

MANZ, U.; PHILIPP, K. Determination of vitamin A in complete feeds and premixes and vitamin concentrates with HPLC. In: KELLER, H.E. (Ed). Analytical Methods for Vitamins and Carotenoids in Food. Basle, Switzerland: Roche, 1988.

MOLINA, M. R.; DE LA FUENTE, G.; BRESSANI, R. Interrelationships between storage, soaking time, cooking time, nutritive value and other characteristics of the black bean (Phaseolus vulgaris). Journal of Food Science, v. 40, n. 3, p. 587-591, 1975. http://dx.doi. org/10.1111/j.1365-2621.1975.tb12534.x

NATIONAL RESEARCH COUNCIL. Recommended dietary allowances. 10th ed. Washington: National Academic Press, 1989. $284 \mathrm{p}$.

PHILIPPI, S. T. Tabela de composição de alimentos - suporte para decisão nutricional. Brasília: ANVISA/FINATEC/NUT, UNB, 2001. $133 \mathrm{p}$.

RAJAGOPAL, L. et al. Carotenoid retention and sensory characteristics of selected vegetables prepared by induction stir-frying. Journal of Food Quality, v. 30, n. 5, p. 703-717, 2007. http://dx.doi. org/10.1111/j.1745-4557.2007.00151.x

SCHRICKER, B. R.; MILLER, D. D.; STOUFFER, J. R. Measurement and content of nonheme and total iron in muscle. Journal of Food Science, v. 47, n. 3, p. 740-743, 1982. http://dx.doi. org/10.1111/j.1365-2621.1982.tb12704.x

SOUZA, A. R. M.; ARTHUR, V.; CANNIATTI-BRAZACA, S. G. Alteration by irradiation and storage at amount of heme iron in poultry meat. Ciência e Tecnologia de Alimentos, v. 27, n. 2, p. 303-306, 2007. http://dx.doi.org/10.1590/S010120612007000200016

SOUZA, A. R. M. et al. Effect of irradiation and storage in the iron availability in lamb meat treated with different diets. Ciência e Tecnologia de Alimentos, v. 28, n. 4, p. 804-808, 2008. http://dx.doi. org/10.1590/S0101-20612008000400007

STATISTICAL ANALYSIS SYSTEM INSTITUTE. Sas/Qc software: usage and reference. 2th ed. Cary, USA, 1996.

STORCKSDIECK, S. G. B. et al. Oxalic acid does not influence nonhaem iron absorption in humans a comparison of kale and 
spinach meals. European Journal of Clinical Nutrition, v. 62, n. 3, p. 336-341, 2008.

SWAIN, J. H.; TABATABAI, L. B.; REDDY, M. B. Histidine content of low molecular weight beef proteins influences nonheme iron bioavailability in Caco-2 cells. Journal of Nutrition, v. 132, n. 2, p. 245-251, 2002. PMid:11823585.

VALENZUELA, C. et al. Total iron and heme iron content and their distribution in beef meat and viscera. Biological Trace Element Research, v. 132, n. 1-3, p. 103-111, 2009. PMid:19475341. http:// dx.doi.org/10.1007/s12011-009-8400-3

VILLALPANDO, S. et al. Distribution of anemia associated with micronutrient deficiencies other than iron in a probabilistic sample of Mexican children. Annals of Nutrition and Metabolism, v. 50, n. 6, p. 506-511, 2006. PMid:17191024. http://dx.doi. org/10.1159/000098142
WHITTAKER, P.; FOX, M. R. S.; FORBES, A. L. In vitro prediction of iron bioavailability for food fortification. Nutrition Report International, v. 39, n. 6, p. 1205-1215, 1989.

WORLD HEALTH ORGANIZATION. Nutrition. 2002. Disponível em: <http://www.who.int/nut/ida.htm >. Acesso em: 10 maio 2002.

WORLD HEALTH ORGANIZATION. Nutritional Anemia. KRAEMER, K.; ZIMMERMANN, M.B. Ed. Sight and Live Press:Basel, 2007. 400p.

WORLD HEALTH ORGANIZATION. Worldwide prevalence of anaemia 1993-2005. WHO Global database on anaemia. BENOIST, B.; Mc LEAN, E.; EGLI, I.; COGSWELL, M. Ed. WHO: Geneva, 2008. 40p.

ZIMERMANN, M. B. et al. Vitamin A supplementation in children with poor vitamin $\mathrm{A}$ and iron status increases erythropoietin and hemoglobin concentrations without changing total body iron. American Journal of Clinical Nutrition, v. 84, n. 3, p. 580-586, 2006. 